\title{
TUGAS PERKEMBANGAN KELUARGA DAN KEPUASAN PERNIKAHAN PADA PASANGAN MENIKAH USIA MUDA
}

\author{
Fatma Putri Sekaring Tyas $^{\left.1^{\star}\right)}$, Tin Herawati ${ }^{2}$, Euis Sunarti ${ }^{2}$ \\ ${ }^{1}$ Program Studi IImu Keluarga dan Perkembangan Anak, Sekolah Pascasarjana, Institut Pertanian Bogor, \\ Bogor 16680, Indonesia \\ ${ }^{2}$ Departemen IImu Keluarga dan Konsumen, Fakultas Ekologi Manusia, Institut Pertanian Bogor, Bogor 16680, \\ Indonesia \\ "E-mail:putrityas27@gmail.com
}

\begin{abstract}
Abstrak
Penelitian ini bertujuan menganalisis pengaruh karakteristik sebelum menikah, karakteristik keluarga, tugas perkembangan keluarga terhadap kepuasan pernikahan. Penelitian menggunakan desain cross sectional dan retrospective studies. Pemilihan tempat penelitian di pilih secara purposive, yaitu di Kabupaten Bogor. Lokasi penelitian di empat desa, yaitu Desa Cibatok 2, Desa Ciaruteun Udik, Desa Cibatok 1, dan Desa Cimanggu 2 Kecamatan Cibungbulang, Kabupaten Bogor. Contoh dalam penelitian ini adalah keluarga utuh yang menikah usia muda (istri berusia dibawah 19 tahun dan usia suami dibawah 25 tahun) dengan lama pernikahan maksimal lima tahun serta memiliki anak pertama usia prasekolah (2,5-5 tahun).Teknik penarikan contoh menggunakan metode purposive sampling. Jumlah contoh yang diambil untuk penelitian ini sebanyak 60 orang. Responden pada penelitian ini adalah istri. Data dikumpulkan melalui wawancara dengan menggunakan kuesioner. Hasil penelitian menemukan tugas perkembangan keluarga termasuk dalam kategori sedang dan kepuasan pernikahan istri rata-ratanya rendah. Hasil uji pengaruh menunjukkan bahwa karakteristik keluarga (lama menikah, pendapatan per kapita, usia istri) memiliki pengaruh langsung positif signifikan terhadap tugas perkembangan keluarga. Tugas perkembangan keluarga memiliki pengaruh langsung positif signifikan terhadap kepuasan pernikahan. Sementara itu, karakteristik keluarga (lama menikah, pendapatan per kapita, usia istri) memiliki pengaruh tidak langsung positif signifikan terhadap kepuasan pernikahan.
\end{abstract}

Kata Kunci: kepuasan pernikahan, pernikahan muda, tugas perkembangan keluarga

\section{FAMILY DEVELOPMENT TASK AND THE SATISFACTION OF MARRIAGE IN EARLY MARRIAGE COUPLE}

\begin{abstract}
This study aimed to analyze the effect of characteristics before married, family characteristics, family development task toward marital satisfaction. The study using designs a cross-sectional study and retrospective study. Location of the research was selected purposively in Cibatok Village 2, Ciaruteun Udik Village, Cibatok 1 Village and Cimanggu 2 Village, District Cibungbulang, Bogor. Sample of this research were intact families who marry at the early age (the wife age's under 19 years old and husband's age under 25 years old) with max five years length of marriage and first child. Respondents in this study were mothers with sampling technique was purposive sampling with a total of 60 people. Data were collected through interviews with using a questionnaire. Family development task in the medium category, and wife's marital satisfaction in the low average. The results showed that the effect of family characteristics (long married, the income capita, age of wife) has a significant positive direct effect to family development tasks. Family development tasks has a significant positive direct effect to marital satisfaction. The family characteristics (long married, the income capita, age of wife) has a significant positive indirect effect to marital satisfaction.
\end{abstract}

Keyword: early marriage, family development task, marital satisfaction

\section{PENDAHULUAN}

Pernikahan merupakan tahapan perkembangan yang harus dilewati dewasa muda. Menurut Undang-Undang Pernikahan Nomor 1 Tahun 1974 Bab 1 Pasal 1, pernikahan adalah ikatan lahir dan batin antara seorang laki-laki dengan seorang perempuan sebagai suami istri dengan tujuan membentuk keluarga (rumah tangga) yang bahagia kekal berdasarkan Tuhan Yang Maha Esa. Pernikahan yang dilakukan pada usia muda merupakan salah satu tantangan keluarga untuk bertahan dalam setiap fase krisis 
perkembangannya. Pernikahan muda adalah pernikahan yang dilakukan oleh pasangan ataupun salah satu pasangannya masih dikategorikan remaja yang berusia di bawah 19 tahun (WHO, 2006). Gambaran pernikahan muda di Indonesia cukup memprihatikan. Indonesia menduduki peringkat ke-37 dari 158 negara dengan persentase pernikahan muda yang cukup tinggi (BKKBN, 2012). Persentase pernikahan muda di Indonesia masih cukup banyak sekitar 11,9 persen perempuan memilih menikah diusia kurang dari 15 tahun. Provinsi dengan persentase pernikahan muda (15-19 tahun) tertinggi adalah adalah Kalimantan Tengah $(52,1 \%)$ kemudian di Provinsi Jawa Barat (50,2\%) (BKKBN, 2012).

Faktor yang mendorong terjadinya pernikahan muda diantaranya kemiskinan, pendidikan, dan pendapatan bulanan yang rendah. Pau, Joseph, dan ljeoma (2013) menyatakan dampak seseorang menikah usia muda adalah ketidakstabilan dalam pernikahan, kesehatannya berkurang, kurang dapat dalam menyelesaikan masalah dengan baik, angka partisipasi sekolah turun, dan berdampak kepada kesejahteraan anak. Menurut Shabbir, Nisar, dan Fatima (2015) perempuan yang menikah muda harus menghadapi banyak permasalahan lingkungan dan sosial sehingga harus dapat beradaptasi. Pernikahan muda yang disertai kurangnya persiapan akan menimbulkan kurang berjalannya tugas perkembangan keluarga dan kepuasan pernikahan. Hal ini yang nantinya akan berdampak terhadap perceraian. Berdasarkan data dari Pengadilan Agama (2015) angka perceraian di Kabupaten Bogor mencapai 400 lebih setiap bulannya, sementara jumlah perceraian yang tercatat dari bulan Januari sampai bulan Juli 2015 sebanyak 2.895 perkara.

Beberapa faktor yang menyebabkan perceraian diantaranya adalah faktor ekonomi, kekerasan rumah tangga (KDRT), kasus perselingkuhan, dan kematangan yang masih kurang dalam membina hubungan rumah tangga. Kelompok usia yang mengajukan kasus cerai gugat pada tahun (2013) yang paling tinggi pada usia 31-40 tahun, dan 21-30 tahun. Tingginya jumlah pasangan suami istri yang melakukan cerai gugat pada kelompok usia 21-30 tahun menunjukkan adanya beberapa pasangan melakukan pernikahan muda. Perceraian ini juga menunjukkan bahwa pasangan yang menikah usia muda tidak dapat melakukan penyesuaian dengan baik sehingga memutuskan untuk berpisah. Kasus perceraian yang terus meningkat mengindikasikan pasangan kurang memiliki kesiapan dan kematangan dalam membina pernikahan sehingga tidak tercapai kepuasan pernikahan. Tsania (2014) pernikahan diusia muda akan berdampak pada kemandirian pasangan dan masih belum stabil serta belum memiliki kesiapan dalam menjalankan fungsi pengasuhan sehingga menyebabkan perkembangan anak terlambat.

Pernikahan erat kaitannya dengan pelaksanaan tugas keluarga. Menurut Sunarti (2001) model fungsi keluarga McMaster (MMFF=McMaster Family Fungsioning) membagi tiga area fungsi keluarga yaitu area tugas dasar (penyediaan pangan, uang, transportasi, dan perlindungan), area tugas perkembangan (berkaitan dengan urutan tahapan perkembangan keluarga) dan area tugas penuh resiko (berkaitan dengan cara keluarga menangani krisis seperti kecelakaan, sakit, kehilangan). Tugas perkembangan keluarga sebagai tugas utama yang nantinya akan menentukan kesuksesan kehidupan (Duvall, 1971). Sunarti (2013) menyatakan tugas perkembangan adalah pemenuhan kebutuhan perkembangan keluarga sebagai satu kesatuan dan perkembangan seluruh anggota keluarga sesuai tahap perkembangan. Tugas perkembangan keluarga dapat terpenuhi jika keluarga dapat mengoptimalkan tugas dasarnya terlebih dahulu sehingga dapat melaksanakan tugas krisis dengan optimal pula. Menurut Paterson (2009) setiap anggota keluarga mempunyai peran masing-masing yang dilakukan secara berulang untuk memenuhi fungsi keluarga, sehingga dapat menyelesaikan dan bertanggungjawab terhadap pelaksanaan tugasnya.Dalam siklus kehidupan keluarga mempunyai tahapan yang berurutan sehingga di dalam masing-masing tahapan perkembangan keluarga mempunyai tugas perkembangan yang harus dipenuhi untuk mencapai tahapan perkembangan selanjutnya. Tugas perkembangan yang terpenuhi akan mengarahkan pada tugastugas perkembangan selanjutnya dan mengarahkan pada kebahagiaan serta kesuksesan keluarga (Duvall, 1971).

Reis dan Sprecher (2015) menyatakan bahwa tugas perkembangan yang berbeda pada masing-masing tahapan perkembangan akan memengaruhi kepuasan pernikahan. Kepuasan pernikahan juga merupakan kondisi mental yang mencerminkan apa yang dirasakan akan bermanfaat. Kepuasan pernikahan meliputi ekspresi afeksi yang terbuka satu sama lain, terjalinnya rasa saling percaya, tidak ada dominasi antara satu 
terhadap lainnya, komunikasi yang bebas dan terbuka antara pasangan, kesesuaian kehidupan seksual, melakukan kegiatan bersama dalam hal aktivitas di luar rumah, tempat tinggal relatif stabil, dan penghasilan memadahi (Duvall \& Miller, 1985). Permasalahan terjadi sepanjang tahapan perkembangan keluarga termasuk pada keluarga dengan anak prasekolah (Duvall, 1971). Fase ini merupakan masa kritis pertumbuhan dan perkembangan anak. Menurut Tsania (2014), masa-masa yang rentan dari kehidupan anak berada pada lima tahun pertama kehidupan yang merupakan pondasi perkembangan selanjutnya. Keluarga dengan anak prasekolah memiliki tanggung jawab dalam mengembangkan pribadi anak terutama dalam hal perilakunya, dikarenakan anak prasekolah mempunyai masalah perilaku yang menyulitkan dibandingkan masalah perawatan fisik. Umumnya, keluarga pada tahapan ini juga berkeinginan untuk menambah anggota baru sehingga dapat menyebabkan krisis pada keluarga (Duvall, 1971).

Setiap tahapan perkembangan keluarga mempunyai tugas krisis yang berbeda-beda. Pelaksanaan tugas krisis ini akan berhubungan dengan kepuasan pernikahan. Menurut Canel (2013) konsep kepuasan sendiri tidak stabil dan berbentuk kurva lonceng karena kepuasan pernikahan cenderung menurun dari tahun ke tahun dan kemudian meningkat di tahun berikutnya. Dabone dan Tawiah (2014) pernikahan di usia muda memiliki resiko ketidakstabilan dalam pernikahan. Ketidakstabilan ini disebabkan kondisi pendidikan yang rendah, kehamilan pranikah, dan budaya pernikahan orang tua sebelumnya. Faktor pendidikan juga dapat berhubungan dengan pengetahuan orang tua dalam melaksanakan tugas perkembangan keluarga.

Penelitian sebelumnya Rahmaita (2015) mengkaji tugas perkembangan dan kepuasan pernikahan pada keluarga dengan anak pertama bayi, sedangkan pada penelitian lebih mengaji keluarga utuh yang menikah muda dengan memiliki anak pertama usia prasekolah (2,5-5 tahun). Apabila keluarga dapat melaksanakan tugas perkembangan keluarga dengan baik maka kepuasan pernikahan akan tercapai secara optimal. Seiring dengan meningkatnya jumlah pasangan menikah usia muda perlu dilakukan kajian mengenai pengaruh tugas perkembangan keluarga terhadap kepuasan pernikahan. Hal ini penting dilakukan sebagai upaya solusi untuk menghadapi kasus pernikahan muda. Berdasarkan latar belakang dan perumusan masalah yang telah diuraikan, maka tujuan penelitian ini adalah (1) mengidentifikasi karakteristik keluarga, tugas perkembangan keluarga,dan kepuasan pernikahan pada pasangan menikah usia muda, (2) menganalisis pengaruh karakteristik sebelum menikah, karakteristik keluarga terhadap tugas perkembangan keluarga dan pada pasangan menikah usia muda (3) menganalisis pengaruh karakteristik sebelum menikah, karakteristik keluarga, tugas perkembangan keluarga terhadap kepuasan pernikahan pada pasangan menikah usia muda.

\section{METODE}

Penelitian ini menggunakan desain cross sectional study, yaitu penelitian dilakukan dengan meneliti pada satu waktu tertentu dan desain retrospective study, yaitu penggalian informasi di masa lalu. Lokasi penelitian di pilih secara purposive, yaitu di Kecamatan Cibungbulang, Kabupaten Bogor. Pemilihan lokasi tersebut dikarenakan mempunyai jumlah penduduk yang cukup padat dan ketersediaan anak usia prasekolah yang cukup banyak. Penelitian ini berlokasikan di empat desa, yaitu Desa Cibatok 2, Desa Ciaruteun Udik, Desa Cibatok 1, dan Desa Cimanggu 2 Kecamatan Cibungbulang, Kabupaten Bogor. Tahapan penelitian terdiri atas persiapan, pengumpulan data, pengolahan data, analisis data, dan penulisan laporan yang dilakukan pada Bulan Juli 2016 hingga Maret 2017.

Penelitian ini memiliki populasi seluruh pasangan yang menikah usia muda di Kecamatan Cibungbulang, Kabupaten Bogor. Teknik penarikan contoh menggunakan metode purposive sampling. Contoh adalah pasangan yang menikah usia muda (istri berusia dibawah 19 tahun dan usia suami dibawah 25 tahun) dengan lama pernikahan maksimal lima tahun serta memiliki anak pertama usia prasekolah (2,5-5 tahun). Jumlah contoh yang diambil untuk penelitian ini sebanyak 60 orang. Responden yang diwawancarai dalam penelitian ini adalah istri.

Jenis data yang dikumpulkan terdiri atas data primer dan data sekunder. Data primer diperoleh melalui wawancara dengan menggunakan kuesioner meliputi: karakteristik sebelum menikah (lama berkenalan dengan pasangan, usia menikah suami dan istri), karakteristik keluarga contoh (usia suami dan istri, lama menikah, jumlah anggota keluarga, lama pendidikan suami dan istri, pekerjaan 
suami dan istri, dan pendapatan per kapita). Jenis skala yang digunakan untuk usia suami usia istri, usia menikah suami dan usia menikah istri, lama perkenalan dengan pasangan, lama menikah, jumlah anggota keluarga, lama pendidikan suami dan istri, pendapatan per kapita memiliki skala data rasio. Kemudian jenis pekerjaan suami dan istri diukur dengan menggunakan skala nominal.

Variabel tugas perkembangan keluarga dan kepuasan pernikahan diukur dengan menggunakan instrumen tugas perkembangan keluarga menurut Duvall (1971). Pernyataan mengenai pemenuhan tugas perkembangan dibagi menjadi dimensi anak dan orang tua, dengan tahapan perkembangan pada keluarga dengan anak prasekolah. Dimensi anak dengan nilai Cronbach's Alpha 0,770, dimensi orang tua dengan nilai Cronbach's Alpha 0,515 , dan total tugas perkembangan keluarga nilai Cronbach's Alpha 0,789. Instrumen dimensi anak terdiri atas 26 item pertanyaan dan dimensi orang tua terdiri dari 18 pertanyaan. Adapun epuasan pernikahan terdiri dari 10 dimensi, yaitu dimensi masalah kepribadian pasangan (5 pertanyaan), dimensi kesetaraan peran (4 pertanyaan), dimensi komunikasi (7 pertanyaan), dimensi penyelesaian konflik (5 pertanyaan), dimensi pengelolaan keuangan (5 pertanyaan), dimensi aktifitas bersama (3 pertanyaan), dimensi relasi seksual (4 pertanyaan), anak dan pernikahan (5 pertanyaan), dimensi keluarga dan teman (5 pertanyaan), dan dimensi orientasi religious (4 pertanyaan). Instrumen ini memodifikasi dari alat ukur ENRICH (Evaluation And Nurturing Relationship Issues, Communication and Happiness) Marital Satisfaction (EMS) dari Fowers dan Olson (1993) dengan nilai Cronbach's Alpha 0,909 totalnya 48 item pertanyaan.

Pengumpulan data dilakukan melalui wawancara, kemudian data diolah dan dianalisis melalui Microsoft Excel, SPSS 16,0 dan smart Partial Least Square (PLS) Techniques. Proses pengolahan data meliputi editing, coding, entry, scoring, dan analisis. Data dianalisis dengan menggunakan analisis deskriptif dan analisis inferensia. Analisis deskriptif digunakan untuk mengidentifikasi rata-rata, standar deviasi, nilai maksimum dan nilai minimum dari karakteristik keluarga (usia suami dan istri, usia menikah suami dan istri, lama perkenalan dengan pasangan, lama menikah, jumlah anggota keluarga, lama pendidikan suami dan istri, pekerjaan suami dan istri, pendapatan per kapita, tugas perkembangan keluarga, dan kepuasan pernikahan. Analisis inferensia yang digunakan untuk pengaruh dengan smart Partial Least Square (PLS) Techniques.

Selanjutnya variabel penelitian diberikan skor penilaian pada setiap pertanyaan kuesioner. Pengukuran dari variabel tugas perkembangan keluarga, setiap jawaban menggunakan pilihan "sering", "kadang-kadang", dan "tidak pernah" dengan skor (3=sering, 2=kadang-kadang, $1=$ tidak pernah). Pilihan jawaban dari kepuasan pernikahan adalah "tidak puas", "kurang puas", "cukup puas", "puas", "sangat puas" dengan skor (1=tidak puas, $2=$ kurang puas, $3=$ cukup puas, $4=$ puas, $5=$ sangat puas. Kemudian skor total dari masing-masing variabel ditransformasikan menjadi skor indeks. Hal ini dilakukan agar memperoleh nilai minimum 0,0 dan nilai maksimum 100,0. Selain itu, bertujuan untuk menyamakan satuan agar perbandingan pengategorian data setiap variabel seragam. Selanjutnya indeks dikategorikan berdasarkan Bloom's cut-off point dari Yimer et al. (2014) untuk mengkategorikan variabel kesiapan menikah dan kepuasan pernikahan. Cut off yang digunakan adalah rendah $(0,0-60,0)$, sedang $(60,0-80,0)$, dan tinggi $(80,0-100,0)$.

Analisis smart Partial Least Square (PLS) merupakan metode analisis yang powerful karena dapat diterapkan pada semua skala data dan tidak membutuhkan banyak asumsi. SmartPLS juga digunakan sebagai konfirmasi teori, membangun hubungan yang belum ada landasan teorinya atau pengujian proporsi, dan pemodelan struktur dengan indikator bersifat reflektif ataupun formatif (Jaya \& Sumertajaya, 2008). SmartPLS tidak mensyaratkan jumlah minimum sampel yang digunakan. Partial Least Square (PLS) dikembangkan sebagai metode umum untuk melakukan pendugaan model struktural yang diukur secara tidak langsung oleh peubah menifes. SmartPLS merupakan suatu teknik statistik multivariate yang banyak melakukan perbandingan antara multiple eksogen dan endogen variabel dengan banyak indikator. Langkah-langkah pemodelan struktural berbasis PLS sebagai berikut: 1) merancang model struktural (Inner mode); 2) merancang model pengukuran (outer mode); 3) mengkonstruksi diagram jalur; 4) konversi diagram jalur ke dalam sistem persamaan, 5) estimasi; 6) goodness of fit; 7) pengujian hipotesis (Jaya \& Sumertajaya, 2008).

Model persamaan struktural Partial Least Square (PLS) digunakan untuk menganalisis pengaruh karakteristik keluarga, tugas 
perkembangan keluarga terhadap kepuasan pernikahan. Pengaruh antarvariabel dinyatakan signifikan ketika memiliki t-hitung lebih besar dari 1,96. Hal ini diperlukan dalam menguji penggunaan alat statistik Partial Least Square (PLS) adalah evaluasi goodness of fit, yaitu pengujian pada outer model (outer loading, Average Variance Extracted, dan composite relialibility) dan inner model ( $R$ square). Nilai outer loading digunakan untuk mengetahui validitas indikator dari variabel yang diteliti. Nilai outer loading lebih besar dari 0,5 menunjukkan bahwa indikator valid dalam menggambarkan variabelnya. Nilai Average Variance Extracted (AVE) digunakan untuk mengetahui validitas dari suatu variabel. Semakin tinggi square root of average variance extracted (AVE) mengindikasikan keragaman dari peubah penjelas yang diakomodasi oleh peubah laten lebih besar dibandingkan dengan jumlah keragaman yang tidak dapat dijelaskan oleh peubah penjelas. Direkomendasikan nilai pengukuran harus lebih besar dari 0,5. Nilai composite reliability ini untuk mengetahui konsistensi dari suatu variabel. Nilai composite reliability lebih besar dari 0,7 menunjukkan variabel penelitian konsisten. Inner model dalam Partial Least Square (PLS) digunakan untuk mengetahui keragaman suatu variabel yang dapat dijelaskan oleh variabel lain dengan melihat nilai $R$-square dari variabel tersebut.

\section{HASIL}

\section{Karakteristik Sebelum Menikah}

Sebelum menikah pasangan suami dan istri melakukan proses berkenalan. Lama berkenalan pasangan suami istri berkisar 1 sampai 72 bulan dengan rata-rata lama berkenalan adalah 22,40 bulan. Hasil penelitian menemukan bahwa usia terendah istri dan suami saat menikah adalah 14 tahun dan 18 tahun. Rata-rata usia istri ketika menikah adalah 17,42 tahun dan rata-rata usia suami saat menikah adalah 22,05 tahun.

\section{Karakteristik Keluarga}

Lama menikah pasangan suami istri berkisar 3 sampai 5 tahun dengan rata-rata lama menikah 4,02 tahun. Usia minimal istri dan suami saat ini adalah 19 tahun dan 21 tahun, dengan rata-rata usia istri 21,40 tahun dan suami 25,97 tahun. Lama pendidikan istri berkisar 6 sampai 12 tahun dan lama pendidikan suami berkisar4 sampai 16 tahun. Besar keluarga dari responden yang berkisar antar 3 sampai 4 orang, dengan rata-rata anggota keluarganya berjumlah 3 orang.Kondisi ini menunjukkan keluarga dalam kategori keluarga kecil. Pendapatan perkapita perbulan berkisar antara Rp133.333,30 hingga Rp2.000.000,00 dengan rata-rata sebesar Rp885.270,00. Berdasarkan BPS (2016) hasil penelitian menunjukkan lebih dari tiga perempat keluarga tergolong tidak miskin dan ditemukan sebagian keluarga hampir miskin. Selanjutnya, ditemukan sebagaian besar istri menjadi ibu rumah tangga (93,3\%) dan lainnya bekerja sebagai wiraswasta, swasta, dan guru. Jenis pekerjaan suami yang paling diminiati adalah wiraswasta $(46,7 \%)$ dan sisanya ada yang menjadi PNS, guru, swasta, dagang, supir, koki, depkolektor, dan lainnya.

\section{Tugas Perkembangan Keluarga}

Tabel 1 menunjukkan bahwa lebih dari dua pertiga capaian tugas perkembangan ibu $(66,7 \%)$ pada kategori sedang dan ditemukan juga seperempat $(25,0 \%)$ capaiannya pada kategori rendah. Hal ini dikarenakan pada dimensi anak sudah cukup baik $(50,0 \%)$, akan tetapi pada dimensi orang tua masih kurang $(66,7 \%)$.

Tugas perkembangan keluarga dibagi menjadi dimensi anak dan dimensi orang tua. Dimensi anak yang capaiannya sedang adalah anak belum dapat menyesuaikan waktu belajar dan bermain serta ibu belum mengajarkan kemandirian kepada anaknya seperti memakai baju sendiri, mengancing dan menggunakan sepatu sendiri. Akan tetapi, capaian yang sudah baik adalah ibu sudah mengajarkan cara berbicara dan merespon kepada orang lain. Hasil penelitian menunjukkan tingkat pengetahuan ibu mengenai pertumbuhan dan perkembangan serta kemandirian anak masih kurang, sehingga lebih dari setengah ibu belum mengajarkan kemandirian kepada anaknya.

Tabel 1 Sebaran kategori tugas perkembangan keluarga

\begin{tabular}{|c|c|c|c|c|c|}
\hline \multirow[b]{2}{*}{$\begin{array}{c}\text { Tugas perkembangan } \\
\text { keluarga }\end{array}$} & \multicolumn{3}{|c|}{ Kategori (\%) } & \multirow[b]{2}{*}{$\begin{array}{l}\text { Minimal- } \\
\text { Maksimal }\end{array}$} & \multirow[b]{2}{*}{ Rata-rata $\pm S D$} \\
\hline & $\begin{array}{c}\text { Rendah } \\
(0,0-60,0)\end{array}$ & $\begin{array}{c}\text { Sedang } \\
(60,0-80,0)\end{array}$ & $\begin{array}{c}\text { Tinggi } \\
(80,0-100,0)\end{array}$ & & \\
\hline Dimensi anak & 18,3 & 50,0 & 31,7 & $38,46-98,07$ & $71,51 \pm 12,69$ \\
\hline Dimensi orang tua & 66,7 & 31,7 & 1,7 & $38,88-83,33$ & $57,82 \pm 11,04$ \\
\hline Total & 25,0 & 66,7 & 8,3 & $40,91-90,91$ & $65,91 \pm 9,79$ \\
\hline
\end{tabular}




\begin{tabular}{lrr}
$\begin{array}{c}\text { Tabel 2 Sebaran } \\
\text { pernikahan }\end{array}$ & kategori & kepuasan \\
\hline $\begin{array}{c}\text { Dimensi kepuasan } \\
\text { pernikahan }\end{array}$ & $\begin{array}{c}\text { Minimal- } \\
\text { Maksimal }\end{array}$ & $\begin{array}{c}\text { Rata- } \\
\text { rata } \pm S D\end{array}$ \\
\hline $\begin{array}{l}\text { Masalah kepribadian } \\
\text { pasangan }\end{array}$ & $25,0-75,0$ & $51,8 \pm 14,98$ \\
Kesetaraan peran & $6,25-75,0$ & $53,43 \pm 14,93$ \\
Komunikasi & $28,57-75,0$ & $63,03 \pm 11,64$ \\
Penyelesaian konflik & $10,0-75,0$ & $58,5 \pm 18,62$ \\
Pengelolaan & $15,0-75,0$ & $53,33 \pm 13,76$ \\
keuangan & & \\
$\begin{array}{l}\text { Aktifitas bersama } \\
\text { Relasi seksual }\end{array}$ & $16,67-75,0$ & $42,5 \pm 18,64$ \\
$\begin{array}{l}\text { Anak dan } \\
\text { pernikahan }\end{array}$ & $25,0-100,0$ & $71,97 \pm 10,25$ \\
Keluarga dan teman & $25,0-75,0$ & $61,25 \pm 9,94$ \\
Orientasi religius & $0,0-75,0$ & $35,10-26,01$ \\
\hline $\begin{array}{l}\text { Total kepuasan } \\
\text { pernikahan }\end{array}$ & $34,89-72,39$ & $56,14 \pm 9,07$ \\
\hline
\end{tabular}

Tugas perkembangan keluarga dimensi orang tua yang capaiannya masih kurang adalah ibu tidak memiliki buku panduan tentang stimulasi dan daftar-daftar stimulasi untuk anak, hampir tiga perempat ibu juga tidak pernah mendongengi anaknya, waktu kebersamaan pasangan suami dan istri, dan ibu tidak dapat menyalurkan hobinya dengan baik. Akan tetapi, juga ditemukan capaian yang sudah baik yaitu hampir seluruh ibu menjaga keharmonisan dengan pasangan, ibu menciptakan komunikasi yang jelas dan lancar, serta menciptakan suasana penuh maaf kepada anggota keluarga yang lain. Hasil penelitian ini menunjukkan bahwa pengetahuan pengasuhan yang belum memadahi sehingga ibu tidak menyadari pentingnya sarana dan prasarana seperti buku untuk panduan menstimulasi anak dan fasilitas belajar untuk menstimulasi anak. Selain itu, orang tua juga belum menciptakan lingkungan yang nyaman untuk anak.

Tugas perkembangan keluarga menunjukkan lebih dari setengah pada kategori sedang. Hal ini dikarenakan pada dimensi anak sudah cukup baik, akan tetapi pada dimensi orang tua masih kurang. Selain itu, hasil ini mengindikasikan bahwa lebih dari setengah keluarga telah siap untuk menjalankan tugas perkembangan keluarga selanjutnya.

\section{Kepuasan Pernikahan}

Istri memiliki capaian kepuasan pernikahan dengan rata-rata skor yang masih rendah yaitu 56,14 . Hal ini dikarenakan masih terdapat beberapa dimensi yang masih tergolong rendah seperti dimensi masalah kepribadian pasangan rata-rata capainnya 51,8 , dimensi kesetaraan peran rata-rata capainnya 53,43 , dimensi pengelolaan keuangan rata-rata capainnya 53,33 , dimensi aktifitas bersama rata-rata capainnya 42,5 dan dimensi orientasi religius rata-rata capainnya 35,10 . Akan tetapi, ditemukan pula dimensi yang sudah baik yaitu dimesi relasi seksual rata-rata capainnya 71,97 (Tabel 2).

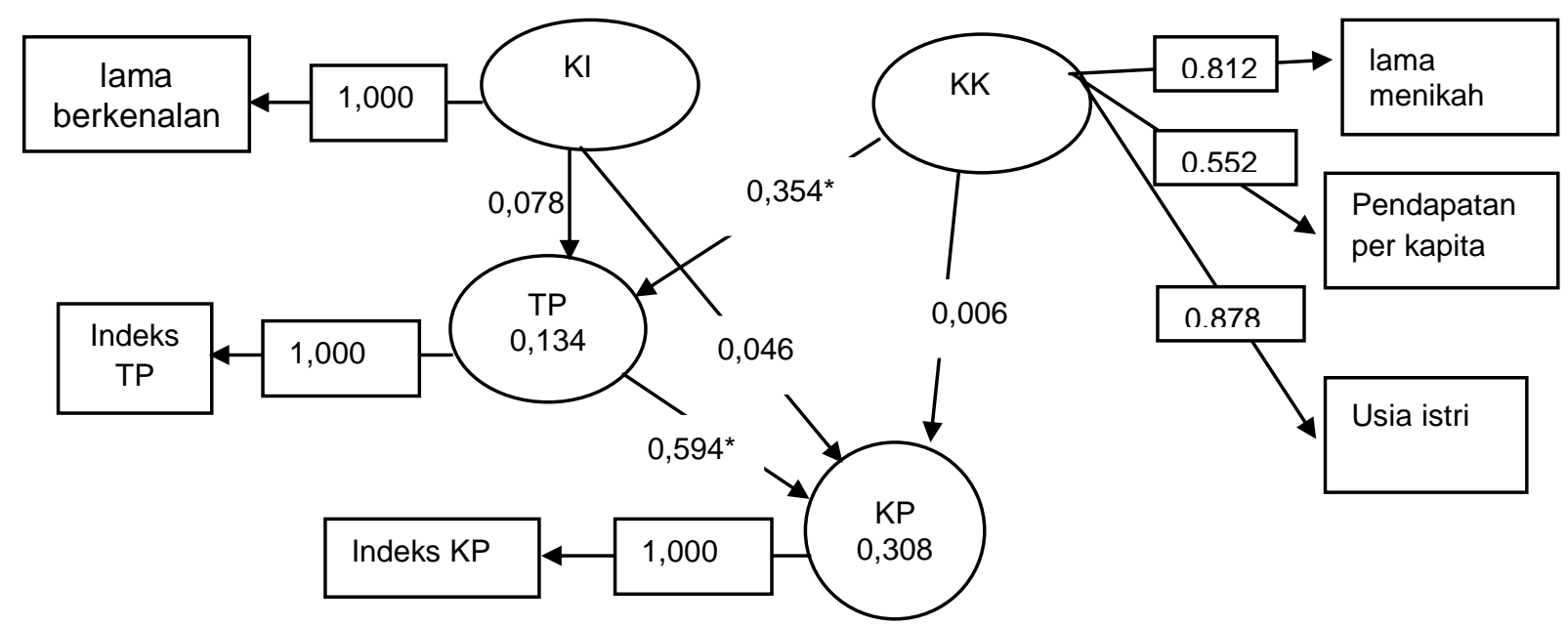

Keterangan :

* signifikasi pada $t>1,96$

$\mathrm{KI}$ : Karakteristik sebelum menikah KK : Karakteristik keluarga

TP : Tugas perkembangan keluarga KP : Kepuasan pernikahan

: Nilai outer loadings

Gambar 1 Pengaruh karakteristik keluarga, tugas perkembangan keluarga terhadap kepuasan pernikahan 


\begin{tabular}{|c|c|c|c|c|}
\hline $\begin{array}{r}\text { Tabel } 3 \text { Koefis } \\
\text { keluar } \\
\text { keluar } \\
\text { pernik }\end{array}$ & & $\begin{array}{l}\text { engaruh } \\
\text { ugas } \\
\text { erhadap }\end{array}$ & $\begin{array}{r}\text { karak } \\
\text { perkemk } \\
\text { ker }\end{array}$ & $\begin{array}{l}\text { teristik } \\
\text { angan } \\
\text { uasan }\end{array}$ \\
\hline \multirow{3}{*}{ Variabel } & \multicolumn{4}{|c|}{ Kepuasan pernikahan } \\
\hline & \multirow{2}{*}{ DE } & \multicolumn{2}{|c|}{ IE melalui } & \multirow{2}{*}{ TE } \\
\hline & & $\mathrm{KI} \mathrm{KK}$ & TP & \\
\hline $\begin{array}{l}\text { Karakteristik } \\
\text { sebelum } \\
\text { menikah } \\
\text { (lama } \\
\text { berkenalan) }\end{array}$ & \multicolumn{2}{|l|}{0,046} & 0,046 & 0,092 \\
\hline $\begin{array}{l}\text { Karakteristik } \\
\text { keluarga } \\
\text { (lama } \\
\text { menikah, } \\
\text { pendapatan } \\
\text { perkapita, } \\
\text { dan usia istri) }\end{array}$ & \multicolumn{2}{|l|}{0,006} & $0,210^{*}$ & 0,216 \\
\hline $\begin{array}{l}\text { Tugas } \\
\text { perkembanga } \\
\mathrm{n} \text { keluarga }\end{array}$ & \multicolumn{3}{|l|}{$0,594^{*}$} & $0,594^{*}$ \\
\hline \multicolumn{5}{|c|}{$\begin{array}{l}\text { Ket: * signifikasi pada t >1,96; DE: Direct effect; IE: Indirect } \\
\text { effect; TE: Total Effect KI: Karakteristik sebelum menikah; } \\
\text { KK: Karakteristik setelah berkeluarga; TP: Tugas } \\
\text { perkembangan keluarga }\end{array}$} \\
\hline
\end{tabular}

Rata-rata kepuasan pernikahan istri masih rendah. Hal ini berarti tidak semua istri dapat memenuhi dan melaksanakan dimensi-dimensi kepuasan pernikahan dengan optimal. Pada dimensi masalah kepribadian pasangan istri masih belum dapat menyesuaikan beberapa sifat dan sikap dari pasangannya. Kemudian pada dimensi kesetaraan peran istri masih masih kurang dengan cara pembagian pekerjaan di rumah dengan suami. Selanjutnya dimensi pengelolaan keuangan istri juga belum puas dengan kondisi keuangan keluarganya, pada dimensi aktifitas bersama istri juga merasa tidak puas dengan cara mengelola waktu bersama. Dimensi orientasi religius istri juga merasa kurang puas dengan cara melakukan ibadah dan ketepatan waktu pelaksaan beribadah.

\section{Pengaruh karakteristik sebelum menikah, karakteristik keluarga terhadap tugas perkembangan keluarga}

Hasil uji pengaruh karakteristik sebelum menikah, karakteristik keluarga (lama menikah, pendapatan per kapita, usia istri) terhadap tugas perkembangan keluarga menunjukkan angka $R$-Square adalah 0,134 (Gambar 1) yang berarti model tersebut menjelaskan 13,4 persen model variabel-variabel memengaruhi tugas perkembangan keluarga dan sisanya 86,6 persen dipengaruhi variabel lain di luar penelitian ini. Karakteristik keluarga (lama menikah, pendapatan perkapita, dan usia istri) $(\beta=0,354 ; t>1,96) \quad(G a m b a r \quad 1)$ berpengaruh langsung positif signifikan terhadap tugas perkembangan keluarga. Hal ini berarti semakin lama pernikahan, semakin matang usia istri, dan semakin tercukupi pendapatan keluarga maka pelaksanaan tugas perkembangan pun akan menjadi lebih optimal.

\section{Pengaruh karakteristik sebelum menikah, karakteristik keluarga, tugas perkembangan keluarga terhadap kepuasan pernikahan}

Hasil uji pengaruh model karakteristik sebelum menikah, karakteristrik keluarga, tugas perkembangan keluarga terhadap kepuasan pernikahan menunjukkan angka $R$-Square adalah 0,308 (Gambar 1) yang artinya model menjelaskan 30,8 persen model variabelvariabel mempengaruhi kepuasan pernikahan dan sisanya 80,4 persen dipengaruhi variabel lain di luar penelitian ini. Hasil penelitian menunjukkan tugas perkembangan keluarga $(\beta=0,594 ; t>1,96) \quad($ Tabel 3$)$ berpengaruh langsung positif signifikan terhadap kepuasan pernikahan. Hal ini berarti semakin baik pelaksanaan tugas perkembangan keluarga maka akan mencapai kepuasan pernikahan yang optimal. Hasil uji pengaruh juga menunjukkan bahwa karakteristik keluarga (lama menikah, pendapatan per kapita, usia istri) memiliki pengaruh tidak langsung positif signifikan $\quad(\beta=0,210 ; \quad t>1,96) \quad$ terhadap kepuasan pernikahan. Hal ini berarti karakteristik keluarga (lama menikah, pendapatan per kapita, usia istri) mempengaruhi kepuasan pernikahan secara tidak langsung melewati variabel tugas perkembangan keluarga.

\section{PEMBAHASAN}

Pernikahan muda salah satunya dipengaruhi oleh faktor geografis (pedesaan/ perkotaan) (Sah 2008). Secara umum pernikahan muda disebabkan apabila keluarga mengalami keadaan kemiskinan dan kerentanan, pendidikan yang masih rendah, budaya yang dipercaya di masyarakat, pergaulan bebas, dan menurunnya kesejahteraan. Palamuleni (2011) umur, wilayah, pendidikan, agama, dan etnik merupakan faktor yang penting menentukan usia pernikahan pertama. Ratarata tingkat pendidikan istri adalah 9 tahun setara dengan jenjang SMP. Fadlyna dan Larasaty (2009) semakin muda usia menikah menyebabkan semakin rendah tingkat pendidikan yang akan dicapai individu. Hasil penelitian Rizkillah (2014) menyatakan bahwa tingkat pendidikan yang tinggi akan memengaruhi jenis pekerjaan dan pendapatan. 
Apabila keluarga memiliki kemampuan dan sumberdaya yang memenuhi maka tugas perkembangan keluarga dapat terlaksana dengan optimal. Salah satu tugas perkembangan yang harus dilakukan keluarga adalah penyediaan kebutuhan fisik keluarga seperti penyediaan tempat tinggal, makanan, pakaian, dan perawatan kesehatan. Tugas perkembangan keluarga dianggap penting dikarenakan agar dapat memahami perubahan yang terjadi dalam keluarga sebagai konsekuensi dari perjalanan dan kehidupan berkeluarga, untuk mengetahui potensi krisis dan kerentanan jika tugas perkembangan keluarga tersebut tidak terpenuhi, untuk mengantisipasi dan menggembangkan ketangguhan sepanjang kehidupan keluarga (Sunarti, 2013). Keluarga dengan anak prasekolah terutama orang tua harus membantu anak untuk mencapai tugas perkembangannya melalui penerimaan berbagai peningkatan keterampilan dan aktivitas fisik anak (Duvall, 1971). Tahapan keluarga dengan anak usia prasekolah harus dapat menyesuaikan terhadap kebutuhan penting dan minat anak usia prasekolah dalam hal melakukan stimulasi dan dukungan untuk tumbuh kembang anak. Selain itu, keluarga juga harus dapat melakukan penyesuaian terhadap berkurangnya energy dan privitasi bagi orang tua (Sunarti, 2013).

Pelaksanaan tugas akan berhasil ditunjukkan dengan keberfungsian suatu keluarga. Pada dasarnya indikator keluarga berkualitas ditentukan dan ditunjukkan oleh pelaksanaan tugas yang detail dalam kehidupan berkeluarga (Sunarti, 2013). Hasil penelitian ini sesuai dengan penelitian Rahmaita (2015) dan Sunarti et al., (2012) menyatakan bahwa tugas perkembangan keluarga pada ketegori sedang. Latifah, Alfiasari, dan Hernawati (2009) faktor resiko yang memengaruhi pengasuhan dan perkembangan adalah pendidikan orang tua yang rendah, pendapatan keluarga yang rendah, pengetahuan tentang pengasuhan yang rendah, serta fasilitas dan sarana prasarana yang masih kurang. Singh, Rai, dan Singh (2012) pendidikan, keadaan sosial ekonomi, demografi merupakan faktor yang memengaruhi kemampuan perempuan atau ibu dalam melakukan pengasuhan dan merawat atau menjaga kesehatan anak. Hasil penelitian Widyana, Toyibah, dan Prani (2015) apabila individu terlalu muda untuk menjadi orang tua maka kesiapannya masih kurang yang menyebabkan tidak dapat menjalankan peran dan kewajiban dalam mendidik dan mengasuh anak.
Keberhasilan dalam pelaksanaan tugas perkembangan keluarga menjadi modal awal membawa keberhasilan tugas berikutnya. Pemenuhan tugas keluarga pada seluruh tahapan perkembangan keluarga akan berkontribusi pada ketahanan keluarga. Duvall dan Miller (1985) pasangan suami dan istri harus mempelajari mengenai pengasuhan sejak remaja atau sebelum menikah. Salah satu prasyarat minimal memasuki gerbang pernikahan adalah individu harus memiliki kematangan usia dan kepribadian untuk menjalankan fungsi, peran, dan tugas keluarga dan berkomitmen melaksanakan keluarga berencana (Sunarti, 2001). Menurut Rahmaita, Krisnatuti, dan Yuliati (2016) semakin baik tingkat pendidikan ibu atau istri maka pelaksanaan tugas perkembangan keluarga akan berjalan dengan optimal. Berdasarkan hasil penelitian menunjukkan bahwa tingkat pendidikan ibu atau istri yang masih kurang sehingga belum memiliki pengetahuan dan kesadaran akan pentingnya sarana dan prasarana yang mendukung pertumbuhan dan perkembangan anak.

Kondisi keluarga yang mengalami transisi dari pasangan suami istri menjadi orang tua akan menyebabkan menurunnya kepuasan. Kepuasan berfokus pada kebutuhan batiniah yang memotivasi perilaku dengan cara-cara tertentu (Nurani, 2004). Lebih dari setengah capaian kepuasan istri masih rendah. Hasil ini menunjukkan tidak semua istri dapat memenuhi masing-masing dimensi dengan baik. Beberapa dimensi yang masih capaiannya kurang diantaranya adalah dimensi masalah kepribadian, kesetaraan peran, pengelolaan keuangan, aktifitas bersama, dan orientasi religius. Akan tetapi, ditemukan pula capaian yang sudah baik yaitu dimensi relasi seksual. Hasil penelitian dimensi masalah kepribadian pasangan menunjukkan istri merasa masih ada sifat, sikap, dan perilaku dari suami yang tidak disukai. Rizkillah, Sunarti, dan Herawati (2015) menyatakan bahwa istri kurang puas dengan kepribadian dari pasangannya dikarenakan masih jarang dipuji oleh suaminya sehingga menyebabkan kepuasan pernikahan belum tercapai. Duvall dan Miller (1985) karakteristik pasangan suami istri yang dapat meningkatkan kepuasan pernikahan adalah saling terbuka dan dapat saling memahami. Pada dimensi kesetaraan peran istri juga masih kurang puas dengan pembagian pekerjaan dan tanggung jawab dalam mengasuh anak ataupun pernikahan. Rahmaita (2015) apabila di dalam keluarga terdapat pembagian peran yang baik antaranggota keluarga maka kepuasan 
pernikahan akan tercapai secara optimal. Galovan et al., (2013); Kwok et al., (2015); Yucel dan Koydemir (2015) keterlibatan anggota keluarga dalam melakukan pekerjaan rumah dan keikutsertaan mengatur pekerjaan rumah tangga akan meningkatkan kepuasan pasangan suami dan istri. Dukungan dari pasangan merupakan hal yang harus didahulukan dibanding sumber dukungan yang lainnya. Tingginya dukungan sosial akan meningkatkan kepuasan pernikahan (Nawaz et al., 2014). Khan dan Aftab (2013) menunjukkan bahwa terdapat hubungan antara persepsi dukungan sosial dengan kepuasan pernikahan. Individu yang melaporkan tingginya dukungan sosial memiliki tingginya tingkat kepuasan pernikahan, rendahnya gejala depresi, dan lebih mampu mengatur stress.

Dimensi pengelolaan uang masih rendah dikarenakan istri masih merasa kurang puas dengan kondisi keuangan, cara mengatur uang, dan masih banyak kebutuhan yang belum dapat terpenuhi. Higginbotham dan Felix (2009); Dakin dan Wampler (2008); Robila dan Krishnakumar (2005); Sunarti et al., (2005) pendapatan, tekanan ekonomi, ketidakstabilan pekerjaan suami akan mempengaruhi kepuasan pernikahan. Rizkillah, Sunarti, dan Herawati (2015) keadaan keuangan atau pendapatan salah satu yang mempengaruhi kepuasan pernikahan. Sunarti (2013) ekonomi selalu menjadi aspek penting dalam kehidupan keluarga. Semakin pendapatan meningkat, kemampuan individu untuk memenuhi kebutuhan finansial juga meningkat (Dew \& Stewart, 2012). Tekanan ekonomi yang disebabkan pengeluaran yang lebih besar dari penghasilan dan hutang. Tingginya tekanan ekonomi ini dapat menyebabkan kehidupan keluarga tidak membahagiakan lagi. Kepemilikian rumah juga mempengaruhi keuangan keluarga karena keluarga perlu menyisihkan uang setiap bulan untuk mengontrak rumah.

Dimensi alokasi waktu bersama masih rendah dikarenakan istri masih kurang puas dengan cara mengatur waktu luang dan merencanakan liburan. Nurani (2004) salah satu yang mempengaruhi kepuasan pernikahan adalah meluangkan waktu bersama. Sunarti (2013) waktu merupakan sumberdaya yang unik, dimana setiap individu maupun keluarga tidak dapat menambahkan atau mengurangi, mengakumulasikan, dan menyimpang waktu. Sifatnya yang unik tersebut maka individu atau keluarga harus mampu mengaturnya sehingga dapat memenuhi tujuan hidup keluarganya.
Dimensi orientasi religius masih rendah dikarenakan istri merasa masih kurang puas dengan cara mengajarkan agama ke anak, cara beribadah dan tertib melaksanakan ibadah. Hasil penelitian Herawati (2012) keluarga di Kabupaten Bogor penerapan fungsi agama belum optimal dikarenakan orang tua masih jarang melakukan kegiatan spiritual dan keagamaan. Mukhlis dan Istiqomah (2015) tinggi dan rendahnya tingkat agama pasangan suami istri akan berkaitan dengan kepuasan pernikahan. Rostami dan Gol (2014) kecerdasan spiritual seseorang akan memprediksi kepuasan pernikahan. Akan tetapi, capaian yang sudah baik pada dimensi relasi seksual, istri merasa puas dengan cara berhubungan seksual dan keterbukaan dalam berhubungan. Lavne, Karney, dan Bradbury (2014) kepuasan pernikahan ditunjukkan dengan rasa cinta dan mengekspresikannya pada pasangan dengan kasih sayang dari waktu ke waktu. Menurut Messmer, Miller, dan Yu (2012) kepuasan seksual yang tinggi akan berkorelasi positif dengan kepuasan pernikahan.

Hasil uji pengaruh menunjukkan bahwa karakteristik keluarga (lama menikah, pendapatan per kapita, usia istri) memiliki pengaruh langsung positif signifikan terhadap tugas perkembangan keluarga. Hasil penelitian ini sesuai dengan Rahmaita (2015) lama menikah, pendapatan per kapita, dan usia istri mempengaruhi tugas perkembangan keluarga. Lama menikah yang lebih lama akan menyebabkan istri atau ibu memiliki pengetahuan dan pengalaman dalam melaksanakan peran dan tugas di keluarga sehingga tugas perkembangan keluarga dapat tercapai secara optimal. Keluarga yang memiliki pendapatan lebih tinggi akan memiliki sumberdaya untuk mencukupi semua kebutuhan pokoknya dan dapat digunakan untuk mencukupi sarana dan prasana mendukung pertumbuhan dan perkembangan anak sehingga pelaksanaan tugas perkembangan keluarga dapat berjalan dengan optimal.

Usia istri yang semakin matang akan membuat istri atau ibu memiliki pengalaman dan pengetahuan yang lebih banyak sehingga pelaksanaan tugas perkembangan keluarga dapat berjalan dengan optimal. Uji pengaruh menunjukkan bahwa tugas perkembangan keluarga memiliki pengaruh langsung positif signifikan terhadap kepuasan pernikahan. Hasil ini sejalan dengan Rahmaita, Krisnatuti, dan Yuliati (2016); Reis dan Sprecheer (2015) tugas perkembangan keluarga berpengaruh 
positif terhadap kepuasan pernikahan. Pelaksanaan tugas perkembangan keluarga yang semakin baik maka semakin baik pula istri dalam melakukan tugasnya merawat dan mengasuh anak, mengatur rumah tangga, mengelola keuangan sehingga akan meningkatkan kepuasan pernikahan. Hasil uji pengaruh menunjukkan bahwa karakteristik keluarga (lama menikah, pendapatan per kapita, usia istri) memiliki pengaruh tidak langsung positif signifikan terhadap kepuasan pernikahan. Hal ini berarti secara tidak langsung karakteristik keluarga mempengaruhi kepuasan pernikahan melewati variabel tugas perkembangan keluarga. Conger, Conger, dan Martin (2010); Kerkmann et al., (2000) lama menikah dan pendapatan keluarga akan mempengaruhi kepuasan pernikahan. Reis dan Sprecheer (2015) menyatakan bahwa usia salah satu yang akan mempengaruhi kepuasan pernikahan.

\section{SIMPULAN DAN SARAN}

Usia menikah istri rata-ratanya 17 tahun dan rata-rata usia menikah suami adalah 22 tahun. Kondisi rata-rata pendidikan istri dan suami adalah jenjang SMP. Keluarga menikah muda terkategori kecil dengan rata-rata pendapatan perkapita per bulan sebesar Rp885.270.Tugas perkembangan keluarga termasuk dalam kategori sedang dan rata-rata kepuasan pernikahan masih rendah. Faktor yang berpengaruh signifikan terhadap kepuasan pernikahan adalah karakteristik karakteristik keluarga (lama menikah, pendapatan per kapita, usia istri) dan tugas perkembangan keluarga.

Berdasarkan hasil penelitian, saran yang dapat diberikan diharapkan memperhatikan kematangan usia menikah sehingga dapat melaksanakan tugas perkembangan keluarga dengan optimal. Keluarga diharapkan dapat mengalokasikan waktu bersama dengan optimal, pasangan suami dan istri dapat melakukan pembagian peran dengan baik, mulai merencanakan dan menabung untuk kebutuhan, serta mendapatkan informasi tentang keagamaan melalui kajian, pengajian sehingga dapat mendekatkan diri kepada Tuhan. Instansi dan perguruan tinggi diharapkan memberikan pengetahuan dan informasi melalui penyuluhan tentang kehamilan, merawat dan mengasuh anak sesuai tahapan perkembangannya, memiliki kesadaran pentingnya sarana dan prasarana stimulasi anak, dan menciptakan kondisi yang nyaman untuk anak agar tercapai kepuasan pernikahan yang optimal. Penelitian selanjutnya diharapkan melibatkan suami dalam wawancara dan melakukan kajian yang berhubungan dengan keluarga menikah usia muda seperti gejala stres, interaksi keluarga, dukungan sosial, dan sebagainya.

\section{DAFTAR PUSTAKA}

Badan Koordinasi Keluarga Berencana Nasional [BKKBN]. (2012). Pernikahan muda pada beberapa provinsi di Indonesia: dampak overpopulation, akar masalah dan peran kelembagaan di daerah. Jakarta (ID): BKKBN.

Canel A. N. (2013). The development of the Marital Satisfaction Scale (MSS). Educational Sciences: Theory and Practice, 13(1),97-117.

Conger R. D., Conger K. J., \& Martin M. J. (2010). Socioeconomic status, family processes and individual development. Journal of Marriage and Family. 72 (6), 685-704

Dabone, \& Tawiah K. (2014). Effects of age on marital satisfaction of married people in Sunyai Municipality. International Journal of research In Social Sciences, 3(8),4857

Dankin J., \& Wampler R. (2008). Money doesn't buy happiness, but it help: marital satisfaction, psychological distress, and demographic differences between low and middle income clinic couples. The American Journal of Family Therapy, 34 (4): 300-311

Dew J. P., \& Stewart R. (2012). A financial issue, a relationship issue, or both? examining the predictors of marital financial conflict. Journal of Financial Therapy. 3 (1): 43-61

Duvall E. \& Miller C. M. (1985). Marriage and family development $6^{\text {th }}$ ed. New York: Harper \& Row Publisher.

Duvall E. M. (1971). Family development: fourth edition. New York (US): JB Lippincott Company.

Fadlyna E., \& Larasaty S. (2009). Pernikahan muda dan permasalahannya. Sari Pediatri, 11(2), 136-140.

Fowers B. J., \& Olson D. H. (1993). ENRICH Marital inventory: a discriminant validity and cross validity assessment. Journal of Family Psychology. 15(1),65-79.

Galovan A. M., Holmes E. K., Schramm D. G.,\& Lee T. R. (2013). Father 
involvement, father-child relationship quality and satisffaction with family work: Actor and partner influences on marital quality. Journal of Family Issues, 20(10), $1-22$

Herawati T. (2012). Manajemen sumberdaya keluarga dan ketahanan keluarga peserta program pemberdayaan masyarakat di pedesaan (Kasus di Kabupaten Bogor) (Disertasi). Institut Pertanian Bogor, Bogor, Indonesia.

Higginbotham B. J., \& Felix D. (2009). Economic predictors of marital quality among newly remarried rural and urban couple. Family Scient Review, 14(2),1830

Jaya I. G. N. M., \& Sumertajaya I. M. (2008). Pemodelan persamaan struktural dengan Partial Least Square (Makalah). Seminar Nasional Matematika dan Pendidikan Matematika. ISSN: 978-97916353-1-8.

Kerkmann B. C., Lee T. R., Lown J. M., \& Allgood S. M. (2000). Financial management, financial problems, and marital satisfaction among recently married university students. Financial Counseling and Planning, 11(2),55-65

Khan F., \& Aftab S. (2013). Marital satisfaction and perceived social support as vulnerability factors to depression. American International Journal of Social Science. 2 (5): 99-107.

Kwok S.Y.C.L., Cheng L., Chow B.W.Y., \& Ling C.C.Y. (2015). The spillover effect of parenting on marital satisfaction among Chinese mothers. Journal Child Fam Stud, 24:772-783

Latifah M., Alfiasari,\& Hernawati N. (2009). Kualitas tumbuh kembang, pengasuhan orang tua dan faktor resiko komunitas pada anak prasekolah wilayah pedesaan di Bogor. Jurnal IImu Keluarga dan Konsumen,2(2),143-153. doi: http://dx.doi.org/10.24156/jikk.2009.2.2.1 43.

Lavner J. A., Karney B. R., \& Bradbury T. N. (2014). Relationship problems over the early years of marriage: stability or change?. Journal of Family Psychology. 28 (6),979-985.

Messmer R., Miller L.D., \& Yu C.M. (2012). The relationship between parent-infant bed sharing and marital satisfaction for mother ofinfants. Family relations, 61(5), 798-810
Mukhlis \& Istiqomah I. (2015). Hubungan antara religiusitas dengan kepuasan perkawinan. Jurnal Psikologi, 11 (2),7178

Nawaz S., Javeed S., Haneef A., Tasaur B., \& Khalid I. (2014). Perceived social support and marital satisfaction among love and arranged marriage couples. International Journal of Academic Research and Reflection. 2 (2): 41-50.

Nurani A. S. (2004). Pengaruh kualitas perkawinan, pengasuhan anak dan kecerdasan emosional terhadap prestasi belajar anak (Tesis). Institut Pertanian Bogor, Bogor, Indonesia

Palamuleni. (2011). Socioeconomic determinants of age at marriage in Malawi. International Journal of Sociology and Anthropology, 3:7,pp: 224-235

Paterson R. (2009). Families first: keys to successful family functioning family role. Communication and Marketing, Collage of Agriculture and Life Sciences. Virginia Polytechnic Institute and State University.

Paul N, Joseph U. O, \& ljeoma O. C. (2013). Education an antidote against early marriage for the girl-child. Journal of Educational and Social Research, 3(5),73-78.

Pengadilan Agama. (2015). Data perceraian. Diambil dari http://www.pa-bogor.go.id. [diunduh 12 Maret 2016].

Rahmaita, Krisnatuti D., \& Yuliati L. N. (2016). Pengaruh tugas perkembangan keluarga terhadap kepuasan perkawinan ibu yang baru memiliki anak pertama. Jurnal IImu Keluarga dan Konsumen, 9(1), 1-10. http://dx.doi.org/10.24156/jikk.2016.9.1.1

Rahmaita. (2015). Pengaruh tugas perkembangan keluarga dan stres ibu yang baru memiliki anak pertama terhadap kepuasan pernikahan (Tesis). Institut Pertanian Bogor, Bogor, Indonesia

Reis H. T. \& Spreccher S. (2015). Encyclopedia of human relationships: marital satisfaction and quality. SAGE Publications.

Rizkillah R. (2014). Kualitas pernikahan dan lingkungan pengasuhan pada keluarga dengan suami istri bekerja (Tesis). Institut Pertanian Bogor Bogor, Indonesia. 
Rizkillah R., Sunarti E., \& Herawati T. (2015). Kualitas pernikahan dan lingkungan pengasuhan pada keluarga dengan suami istri bekerja. Jurnal Ilmu Keluarga dan Konsumen, 8(1), 10-19. doi: http://dx.doi.org/10.24156/jikk.2015.8.1.1 0 .

Robila M. \& Krishnakumar A. (2005). Effect of economic pressure on marital conflict in Romania. Journal of Family Psychology, 19(2), 246-251.

Rostami A.M., \& Gol H.C. (2014). Prediction of marital satisfaction based on spiritual intelligence. Social and Behavioral Sciences, 116: 2573-2577

Sah N. (2008). How useful are the demographic surveys in explaining the determinants of early marriage of girls in the Terai of Nepal?. Journal of Population Research, vol. 25 (2):207-222

Shabbir S., Nisar S. R., \& Fatima S. (2015). Depression, anxiety, stress, and life satisfaction among early and late marriage females. European Journal of Business and Social Sciences, 4(8),128131.

Singh L., Rai R. K.,\& Singh P. K. (2012). Assessing the utilization of maternal and child health care: among married adolescent women: evidence from India. Journal Biosoc. 44, 1-26.

Sunarti E. (2001). Studi ketahanan keluarga dan ukurannya: Telaah kasus pengaruhnya terhadap kualitas kehamilan (Disertasi). Institut Pertanian Bogor Bogor, Indonesia.

Sunarti E. (2013). Ketahanan keluarga. Bogor (ID): IPB Press.
Sunarti E., Simanjuntak M., Rahmatin I., \& Dianeswari R. (2012). Kesiapan menikah dan pemenuhan tugas keluarga pada keluarga dengan anak usia prasekolah. Jurnal Ilmu Keluarga dan Konsumen, 5(2), 110-119.

http://dx.doi.org/10.24156/jikk.2012.5.2.1 10.

Sunarti E., Tati, Nurani A. S., Noorhaisma R., \&Lembayung D. P. (2005). Pengaruh tekanan ekonomi, dukungan sosial, kualitas pernikahan, pengasuhan, dan kecerdasan emosi anak terhadap prestasi belajar anak. Media Gizi dan Keluarga, 29(1), 34-40.

Tsania N. (2014). Karakteristik keluarga, kesiapan menikah istri dan perkembangan anak usia 3-5 tahun (Tesis). Institut Pertanian Bogor, Bogor, Indonesia.

Widyana E. D., Toyibah A., \& Prani L. P. M. E. (2015). Pola asuh anak dan pernikahan muda. Jurnal Pendidikan Kesehatan, 4(1),33-39.

World Health Organization [WHO]. (2006). Married adolencents: no place of safety. Geneva, Switzerland $(\mathrm{CH})$ : WHO Press.

Yimer M., Abera B., Mulu W., \& Bezabih B. (2014). Knowledge, attitude and practices of high risk populations on louse-borne relapsing fever in Bahir Dar City, North-West Ethopia. Science Journal of Public Health, 2(1),15-22.

Yucel D, \& Koydemir S. (2015). Predictors of marital satisfaction in North Cyprus: exploring the gender effects. Journal of Family Studies, 21(2), 120-143. 